\title{
A review of the problems and challenges in the study of microbiology in Nigeria's tertiary institutions
}

\author{
Ugwuanyi, R. C.
}

Department of Science Laboratory Technology, Institute of Management and Technology, Enugu, Nigeria

\section{Key Words:}

Microbiologists

Challenges

Tertiary institution

Received: 10 December 2014

Accepted: 26 March 2015

Published: 22 February 2016

\begin{abstract}
Microbiology is the study of microscopic living organisms; bacteria, fungi, algae, protozoa, and viruses. It encompasses numerous sub-disciplines, including virology, mycology, parasitological, bacteriology and biotechnology. Microbiologists work in microbiology, studying microbes, their interaction with the environment, and their effects on man and other living organisms. Due to the relevance of microbiologists in research, healthcare, environmental studies, agriculture, food security, and biotechnology, the need for qualified and well-trained microbiologists in Nigeria continue to grow. Nigeria is one of the fastest-growing economies in Africa. Therefore the need and adequacy of Nigerian university and polytechnic graduates in microbiology are of great concern, especially those graduates seeking employment and employers of labor in the field of microbiology. A large vacuum seems to exist between these graduates and the labor market demand. This work exposes and highlights the problems and challenges in microbiology in Nigerian universities and polytechnics. It will suggest solutions and recommendations alleviate these problems and encourage active and functional teaching and learning processes in microbiology.
\end{abstract}

(C) 2016 The Author(s). Published by TAF Publishing.

\section{INTRODUCTION}

Microbiology plays a central role as one of the basic biological sciences and has been at the fore front of research aimed at probing the nature of life process [1]. During the past several decades many of the major discoveries which have helped to elucidate the fundamental principles of molecular biology, biochemistry and genetics have arisen from studies using micro-organisms.

The standard of microbiology graduates that leave our tertiary institutions is of great concern to employers of labor and of their poor preparedness for work. They believe that academic standards have fallen considerably over the past decades and a degree from tertiary institutions is not a guarantee of communication skills or technical competence [2].

Microbiology offers some of the most exciting and challenging careers in fields of science and medicine [3]. These include research microbiologists who work in laboratories in universities, Polytechnics, biotechnology companies, and agricultural, medical and veterinary and research institutes. They investigate the molecular and physiological mechanisms employed by micro-organisms associated with infectious diseases, environmental processes and biotechnology. The needs for qualified microbiologists continue to grow

\footnotetext{
${ }^{*}$ Corresponding author: Ugwuanyi, R. C.

†Email: rosemaryugwuanyi@gmail.com
} 
both for basic research and practical applications [4]. The Nigerian government has majority control of Tertiary education and has several agencies in charge, such as the Nigerian University Commission (NUC), National Board for Technical Education (NBTE) etc. Consequently, the Federal Government of Nigeria has adopted education as an instrument for sustainable national development. Nigeria's philosophy of education is based on the integration of the individual into a sound and effective citizenry. In addition to the number of universities and Polytechnics are vocational colleges which were established to train technical low-level and middle-level manpower are in their numbers in the country. A lot of these institutions award degrees and diplomas in microbiology. The study of microbiology is almost as old as the establishment of tertiary institutions in Nigeria, but the standard of the graduates are seriously diminishing to the lowest level. This decrease has been a steady but gradual process that has eventually resulted in poor quality microbiologists in the field of work and in the labor market.

\section{Objective of the Study}

This study is aimed at reviewing the problems and challenges associated with the study of microbiology in Nigerian tertiary institutions, suggesting solutions and recommendations to ameliorate these problems.

\section{Problems in the Study of Microbiology}

The adequacy of Nigeria universities and polytechnics microbiology graduates remains hotly debated. It is a question of particular concern to graduates who are seeking employment and to employers who consider employing them [5]. As observed by many researchers, some of the problems that resulted to this poor standard of study of microbiology in Nigerian tertiary institutions include the following:

\section{Inadequate Funding}

According to Andrew et al. [6] a large mismatch appears to exist between university output and labour market demand. At the same time, their findings show that the employment prospects of recent microbiology graduates have clearly deteriorated. This primarily because funding shortages; the negative influence of a corruptive and valueless political system; and planning and implementation problems [7].

Anyanwu et al. [8] Reported a lower rating on the "reputation" of first generation Nigeria university graduates (established between 1948 and 1965, following the recommendation of Ashby Commission set up by the British Colonial Government to study the needs for university education for Nigeria). They expressed a belief that the quality of university education has fallen. A similar study conducted by Ugwuonah et al. [2] on another Nigeria university reported that those who graduated in the 1980s gave more favorable rating to questions regarding availability of study resources than those who graduated in the 1990s these are the second generation graduates (established between 1970 and 1985).

The study of microbiology at any level requires a lot of funding to meet with the demand of it relevancy but that fact have long been overlooked by the people who are responsible. A comparison between the stunted growth of the universities established since the 1980s and the rapid growth of those that were established in the preceding two decades further demonstrates the gap in funding. Ironically, those earlier universities were built with little or no oil money [1]. 


\section{Poor Teaching Facilities and Infrastructure}

Longer et al. [9] pointed that it is the responsibility of our educational system to provide graduates with the background and skills necessary to be successful in their chosen fields of endeavour. For this reason, when employers recruit graduates, they look for graduates from institutions with curricula that use new technology and emphasize current practices. In another tracer study Omoifo et al. [10] found that microbiology graduates of Nigerian universities rated supervised practical work and quality of academic advice received as very poor. Graduates of microbiology and and other sciences, only 29 percent rated equipment, laboratories, and workshops as very good. On the whole, graduates felt that teaching facilities and infrastructure were the worst aspects of the university environment, followed, by staff qualifications and living conditions.

A this day Newspaper report (this Day Newspaper June 5th, 2005) shows that older cohorts awarded higher scores to question on opportunities to undertake research, participate in supervised work experience, and have access to technical and laboratory resource. A casual interview of graduates in microbiology both in university and polytechnics show that only few find most of the theories they learn in schools applicable in their daily work. They in particular, rated the practical aspects of their education very poorly.

Libraries have become archives of state, archaic, and irrelevant materials. Hence, the poor quality of graduates is also caused by a shortage of learning resources. Most university and polytechnics microbiology libraries are reported to hold out-of-date collections while some have no such facilities.

Akinnaso [7] pointed out that mostly affected are infrastructure (buildings, roads, power, and water resources); knowledge facilities (library accessions, computing facilities, and teaching aids); research funding; recreational facilities; and welfare packages for lecturers, administrative staff, and students. They are either inadequate or nonexistent. In the case of students, for example, investment in university housing was withdrawn, leading to sharp increases in squatting in the few hostel facilities available and off-campus housing for most students. As a result, many students these days go through the university without the university going through them, as the cliché goes. Those who attended or taught at any premier university between 1965 and 1985 could easily appreciate the extent of depreciation of necessary physical structures and facilities.

\section{Decline of Staff Quality}

The decline of staff quality is a consequence of obsolete research facilities, especially in our public institutions. Laboratories are not well equipped or are practically non-existent. Andrew et al. [6] report that a respondent from a manufacturing firm noted that instructors from some of the local universities do not have copies of basic texts that are available in the corporate library and are essential reading for the relevant and recent innovations in the study of microbiology.

Motivation to do research and publication is very low. Research grants, though available, are not sought, and sometimes the rigours involved makes obtaining these funds frustrating. Adeyemi et al. [11] posit that, "There is no gainsaying that curriculum planning and physical expansion without adequate and sustainable human and material resources would definitely fail to reproduce the desired results". The ability of polytechnics to produce quality microbiology graduates depends largely on the quantity and quality of teachers available. Ayodeji [5] says that, "Teacher adequacy is a function of many factors, which include funding, student enrollment over time, and staff turnover. 
Ephraim [12] reiterates that Nigerian public institutions have high enrolments without enough qualified institutions based on infrastructures and quality and quantity of staff. As a result, staff/student ratios have worsened to the detriment of student learning and academic research. Several international agencies have provided scientific and technological research and development support. The Nigerian government has an annual budget of huge money for some of these agencies, but to what extent have Nigerian academics taken advantage of grants and research collaboration with these agencies is always the question till date.

The decline in the quality of microbiology graduate in Nigeria has become too glaring within the past 20 years to be glossed over by anybody who is aware of the role of microbiology in the society [9]. The over direction of student teachers of colleges and university lectures which results in the lack of proper imagination and initiative on the part of most student teachers, makes them depend on lecturer's notes, handouts, and examination materials thereby leading to the production of low quality teachers [13].

\section{Brain Drain}

Summarizing the factors that contributed to this decline from late 1988 to 1996 , and subsequent collapse from 1997 to date, Okebukola et al. [14] states this as part of his findings overloaded teaching and administration schedules which leave little time for research, and diminishing ability of seasoned and senior researchers to mentor junior researchers due to brain drain. In the past two decades no graduate of microbiology from a government institution (both federal and state) was not a victim of reasonable period of strike most times this strike do not affect the graduation year but finally affect the quality the graduates as so many institutions rush to meet up with the new session at the expense of the expected knowledge. As student populations outstripped available lecture spaces and teaching resources, lecturers became overburdened with crowded classrooms and excessive grading responsibilities. Poor remuneration further dampened their morale [7].

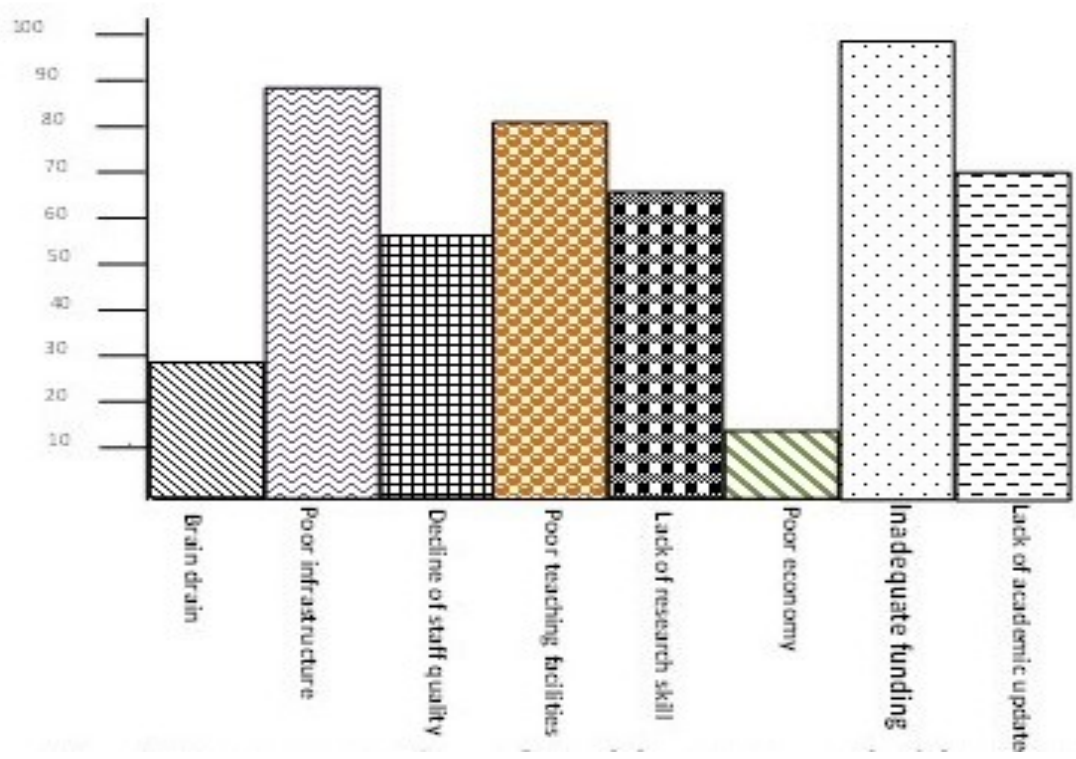

FIGURE 1. Representation of problem as graded by the students 


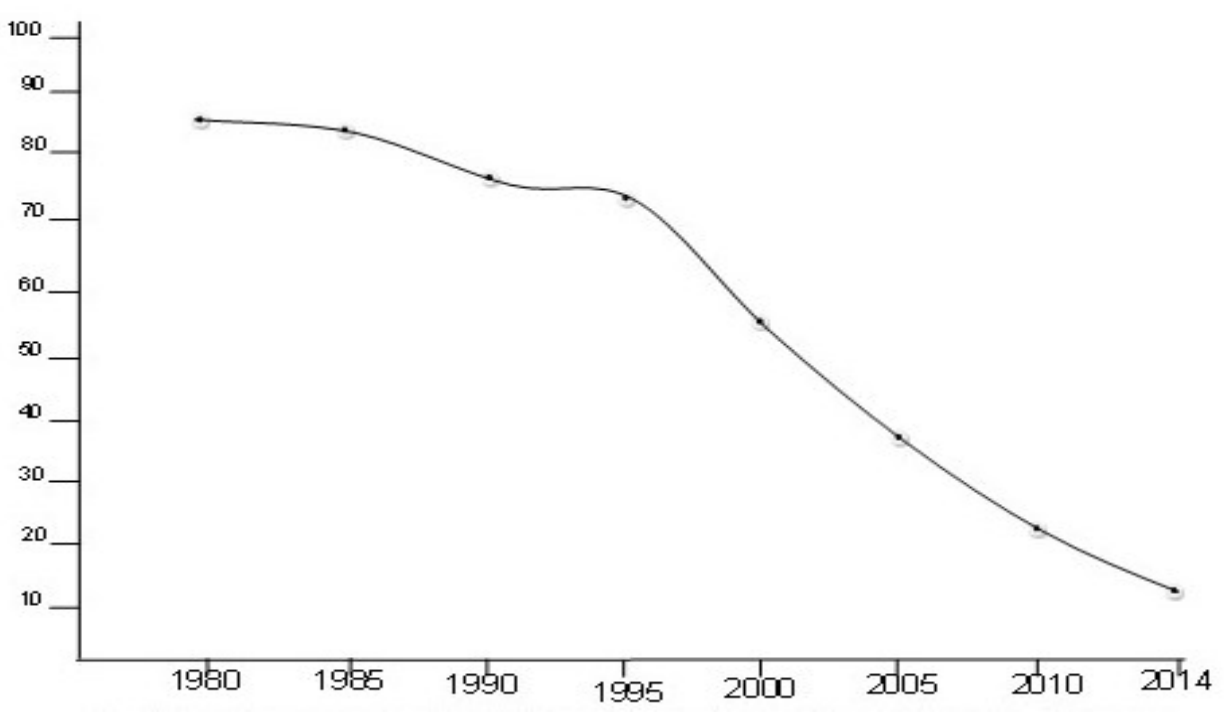

FIGURE 2 . Analysis of trends in the standard of study of microbiology in Nigeria from 1980 till date

\section{SOLUTIONS TO THE PROBLEMS IN THE STUDY OF MICROBIOLOGY IN TERTIARY IN- STITUTIONS IN NIGERIA Funding}

Education funds refer to budgetary allocations that are readily available or that are going to be made available at a stated time by governments or institutions for the purpose of paying salaries, allowances and benefits, and the building and provision of educational infrastructures to aid teaching and learning. Education funding in Nigeria has gradually been on the rise culminating in an eleven percent allocation in the year 2006 budget. Nigeria has struggled to meet the 26 percent allocation recommended by UNESCO as a means of attaining quality education and education for sustainable development 2005-2014. Despite improved budgetary allocation to the education sector in Nigeria, the condition of the sector remains worrisome. Conditions of facilities are still a far cry from acceptable basically due to past underfunding and systemic corruption.

Education is an essential service that must be scrutinized, monitored and constantly evaluated and fully exercised from the grip of corruption if we are ever going to attain the standard of education we once enjoyed. This realization has elicited stringent calls for effective utilization of funds to solve the myriad of problems in the education sector. The impact of corruption is pervasive both in terms of the drain on national resources and its corrosive influence on institutional efficiency and service delivery in all sectors [13].

\section{Teacher Education}

One of the means to end one of the most serious problems reviewed is a serious academic research orientation among the academic staffs in Nigeria institutions of higher learning specifically microbiology because of high need for recent experience and current findings in this field of study.

Effective teaching is an intelligent, knowledge-based activity that takes proper account of teachers' professionalism. This understanding stems from the condition that teaching education and training are an embodiment of professional development.

A lot of researchers suggest teacher education and update seminars from time to time. The dimensions of teacher education and preparation of teachers include the nature and 
extent of guidance given to them. Their success in teaching depends on their knowledge, attitude toward teaching, academic self-concept and explicit understanding of the profession. Teacher education and preparation, therefore, provide teachers with knowledge, skills and aptitude to be familiar with the art and science of teaching that in turn gives them confidence to carry out their task. In the same vein, the purpose, relevance, degree of structure, methods of teaching and management of teaching provide success for classroom practices [5]. According to Karani [15] the main objectives of teacher education are to develop awareness, knowledge, attitudes, skills, evaluation ability and full participation in the teaching and learning process.

\section{Adequate Administration and Planning Process}

A very remarkable problem that has inhibited effective teacher education programs over the years in Nigeria is lade of effective administration and planning because the success of any educational system is hinged on proper planning, efficient administration and adequate financing [14]. This problem is not peculiar to developing countries; educational institutions in developed countries still compete for public funds with other sectors of the economy so that they can improve the quality of the resources available for teaching and learning. When made available, the resources are to be put into maximum use so that educational objectives can be achieved [16]. Educational administration, planning and man power training, and development have evolved as a discipline to guide the allocation and utilization of educational resources both human and material in the school system. This is required to arrest areas of wasted resources to make educational production more effective. In this regard, educational administration, planning and manpower training and development have become indispensable tools in the management of activities in all spheres of life. Educational administration here includes essentially a services, activity or tool through which the fundamental objectives of the educational process may be more fully and efficiently realized. It is the activities of educational organization as geared towards the attainment of goals of teaching on the part of teachers and learning on the part of learners [10]. Administration includes organization and structure, proprietorship and control, inspection and supervision. The function may be discharged efficiently with a cadre of staff that is adequate in numbers and quality.

\section{Quality Accreditation and Productivity}

There was an urgent need, the communiqué said, "to restore the integrity of higher education institution in terms of work, ethics and morality, transparency, productivity, democratization and total commitment to the ideals of the ivory tower". Universities should give primary to developing a vision and strategic plan, and should have structures for self monitoring internal efficiency and quality assurance. "The dialogue agreed on the need for some pragmatic reforms in curriculum and teaching methods to engender more practical, conscious and critical learning and studentship". It warned against the "hasty rush to force teach entrepreneurship" and said a practical approach was needed to develop graduate entrepreneur in all fields. According to the communiqué, the government needed to be more cautious in establishing or approving new universities without "Commensurate increase in the number of teachers, as this has the potential to spread available human resources standards". Indeed, Nigeria needs to holistically plan the growth of its higher education system in terms of mix, typology and functionality on relation to relevance, riches, matching labour market and developmental needs, and the desire to nature globally competitive institutions. 


\section{CONCLUSION}

Research and publication remains a yardstick for promotion in academics in Nigeria. The major area of concern remains the study of microbiology in polytechnics and universities, where results from this research have revealed poor research output. The problems developed gradually and can as well be handled gradually for effective result.

\section{RECOMMENDATIONS}

It is recommended therefore that:

i. The government at all levels should create channels to monitor funds that are specifically for education.

ii. NUC and NBTE should encourage researchers with grants and collaboration with other researchers across the world. The NBTE will have to review the promotion criteria in Nigeria polytechnics.

iii. Research output should be used as an essential aspect of assessment for academic positions in Nigeria rather than certificate.

iv. Quality accreditation should be encouraged at all times as that will always bring to limelight the areas of urgent attentions in the course of the study in the institutions.

These recommendations will ameliorate the dwindling research output from Nigeria polytechnics and further encourage active research practices among Nigeria universities. v. Most importantly, microbiology laboratories and libraries of our tertiary institutions should be well equipped in order to meet the challenges of students and academic staff in the process of teaching and learning.

\section{REFERENCES}

1. Nester E, Anderson D, Evans Roberts C, Nester M. Microbiology: A human perspective. New Delhi, IN: McGraw Hill Publishers; 2009.

2. Ugwuonah G, Omeje K. Higher education and the demand for manpower development on the Nigeria manufacturing sector: An empirical study of Enugu and Anambra states. Journal of Industrial Standardization in Nigeria. 1998; 2(5): 507-519.

3. Madigan M, Martinko J. Brock biology of microorganisms. London, UK: Pearson Education Press; 2006.

4. Tang YW, Persing DH. Encyclopedia of microbiology. London, UK: Oxford Academic Press; 2009.

5. Ayodeji $O$. The crisis of research and academic publishing in Nigerian universities: The twentieth century and beyond. Paper Presented at: The 28th Annual Spring Symposium, African Universities (CODESTRIA), Dakar, SN; 2002.

6. Andrew D, Bankole 0, Olatunde A. Labor market prospects of university graduates in Nigeria. Nigeria University System Innovation Journal. 2000; 10: 88-97.

7. Akinnaso N. University education in Nigeria problems and solutions. Punch Newspaper; 2012.

8. Anyanwu GA, Iloeje IC. Graduates employment survey: A tracer study of the graduates of the facilities of arts, agriculture and education of the University of Nigeria. Nigeria University Innovation Journal. 1996; 11: 92-112.

9. Longer O, Uwadia C, Longe F. An X-ray of potentials for collaboration between the academic and the industry. Paper presented at: The 8th International Conference of the Nigeria Computer Society. 2005; 5(1): 121-133.

10. Omoifo C, Badmus G, Awanbor D. Education and achievement in the early career of the University of Benin graduates. Report of 1996 University of Benin graduate Survey, Faculty of Education, University of Benin, Benin, NG; 1997.

11. Adeyemi J, Uko Aviomoh E. Effective technological deliver in Nigerian polytechnics: Need for academic manpower development policy. Education Policy Analysis Archives. 2004; 12(24): 201-212.

12. Ephraim EO. Research and technological development in Nigeria. Journal of Science and Technology. 2004; 5(2): 266-278. 
13. Sobo B. Universities, research and development in Nigeria: Time for a paradigmatic shift. Paper Prepared for: 11th General Assembly of CODESRIA on Rethinking African Development Beyond Impasse: Towards Alternatives, Maputo, MZ; 2005.

14. Okebukola P, Solowu OM. Surely of university education in Nigeria. Journal of Curriculum Studies. 2001; 223(2): 333-352.

15. Karani F. Higher education in Africa in the 21st century. Paper presented at: The Africa Regional Consultation Preparatory to the World Conference on Higher Education, Dakar, SN; 1997.

16. Cetto A. Scientific journal publishing in the developing world. Lessotho Coosted, IN: Chennas Publishers; 1998.

— This article does not have any appendix. - 